\title{
VISUAL IDENTIFICATION OF RURAL TOURISM FACILITIES IN POLAND
}

\author{
Karol KRÓL ${ }^{1 *}$, Dariusz ZDONEK ${ }^{2}$ \\ ${ }^{1}$ University of Agriculture in Krakow, Faculty of Environmental Engineering and Land Surveying; \\ k.krol@onet.com.pl, ORCID: 0000-0003-0534-8471 \\ ${ }^{2}$ Silesian University of Technology in Gliwice, Faculty of Organization and Management; \\ dariusz.zdonek@polsl.pl, ORCID: 0000-0002-6190-9643 \\ * Correspondence author
}

Purpose: The subject of the research were the logos of individual facilities of rural tourism in Poland found on the websites of these facilities.

Design/methodology/approach: The research covered 243 websites hosted on paid domains. A semantic, formal and aesthetic analysis of graphic signs was conducted. The research was conducted by way of exploratory method. Logos were found on 202 websites. 41 facilities did not use a graphic sign. In 112 cases the logo was composed of a symbol and logotype.

Findings: In 147 cases the logos had a traditional form (traditional, neutral, rustic) or used elements associated with rural areas. In 49 cases, the logos were assessed as modern. Originality/value: What was noted was the fact that in hyper-text documents, logos perform numerous functions. Apart from making the navigation easier, they can also have a dynamic, multimedia form. On the basis of analysis of graphic signs, two main types of rural tourism facilities were distinguished: "traditional" and "commercialized" ones.

Keywords: image management, corporate identity, logo, logotype, graphic sign.

Category of the paper: Research paper.

\section{Introduction}

In rural areas one can find various accommodation facilities offering a wide array of additional services, including gastronomic services or those pertaining to organization of special events (Ciepiela, 2016). A majority of these facilities evolved from agricultural farms, agritourism farms, which is in some way a consequence of tourism development in rural areas. In areas attractive for tourists, the agritourism activity quite often is one of the development stages. The economic success of an agritourism farm often results in its transformation into tourist facility, offering (accommodation) services in rural areas (Bednarek-Szczepańska, 
2010). Majority of rural tourism facilities undergoes a "metamorphosis" of sorts - starting from agricultural farms offering traditional agritourism product, through specialized ones but still carrying out agricultural activity, to facilities offering services on a large scale.

When it comes to promoting services they offer, the owners of rural tourism facilities in Poland more and more boldly use the possibilities of the Internet. It results from the growing availability of digital forms of promotion. These forms are not limited to a single website. One can mark one's presence in the digital world with the use of social media, industry websites or message boards. It also results from the pressure being the result of search of competitive advantages. The use of the Internet in business activity can increase the effectiveness of the undertaken activities and represent competitive advantage. It concerns mostly rural tourism facilities that carry out their activity on a larger scale.

The Internet ecosystem is constructed in such a way that various forms of activities in the network usually foster the increase of effectiveness of one's own website, recognition of one's brand, promotion and sale of own products and services. The use of the Internet allows to increase the offer range and overcome the limits associated with time and space. Individual website is a place where the traffic accumulates (it is a diversified traffic as it results from the diversification of traffic sources), transactions are finalized, a place where the objective conversion should take place, understood as a closure of sales process. A website is supposed to facilitate and encourage it. It would not be possible without the aesthetics of performance, visual identification and consistent message (Cai and $\mathrm{Xu}, 2011$ ).

The specifics of the Internet oriented towards visual communication in a way forces the content creators to use multimedia. Their main objective is to increase the message attractiveness. Digital forms of presentation made available in the network influenced the form of interaction between the customers and service providers. In the electronic channel it was necessary to cause or strengthen the sensory effect, first of all visual and audio effect of presence of an entity being a service or product provider. Traditional forms of presentation of offer advantages with the use of text and images can be insufficient to express their attractiveness. A demand emerged to assign them identity and to build a brand that can be visually identified. Most frequently this is carried out by multiple use of unique graphic sign. This also becomes useful for the purpose of presentation of rural tourism facilities.

The aim of this paper is to identify the most frequently used forms of visual identification on websites of rural tourism facilities in Poland. At the same time, it was assumed that the main element of visual identification are logos that are the theme of a website. 


\section{Corporate identity and its visual identification}

Corporate identity is the totality of activities that aim to trigger a defined image. It is an enterprise image properly planned and shared in the market environment (Mruk, 2004). World Tourism Organization (UNWTO) defines identity as individual or collective image of the destination (Cooper et al. 1993). An image is a set of beliefs, thoughts and experiences of a given subject (person or group) on a given object; object can be understood as company, product, brand, place or person. Such an image can be true or false and result from own experience and imagination. It tends to be subjective and depends on the desires, wishes, fears, experiences and superstitions (Tkaczyk and Rachwalska, 1997).

The corporate identity is a logical whole composed of symbols, behaviours and message created by the organization to increase the recognition and differentiate the brand on the market (Luczak, 2010). It is a unique set of features and activities that allows to distinguish it from other competitive entities and make it recognizable. The base of the corporate identity is the nature of the enterprise that is reflected in the communication and behaviour patterns. The corporate identity should be perceived as a whole composed of such elements as name, history, reputation, philosophy and strategy, organizational culture, management style and behaviour of employees. Corporate identity covers visual and non-visual aspects such as: (1) corporate attitude, (2) corporate behaviour and (3) corporate communication (DewalskaOpitek, 2010). With their use, the enterprise marks its presence and presents its objectives and ideas. The corporate identity is also composed of communication patterns that are expressed with the use of unique set of features that allows to distinguish it, give it "personality" and rank (Frączek, 2017).

The basis of corporate identity is its visual identity that is a complex system comprising first of all a graphic sign (Kruszewski, 2011). Visual identification is a set of various elements (graphic, typographic and others) together with set of guidelines on their use. It is one of the four pillars of identity system of a given entity - next to attitude, behaviour and communication (Mruk, 2004). Visual identification is composed of trade name, logo and company symbols, characteristic colours and typography.

\section{System of visual identification}

System of visual identification is a set of various graphic elements that makes it possible for the recipients to identify a given entity and to distinguish it from competition. Symbols identifying the entity can take on visual or verbal forms. Verbal forms are the name, slogans and advertising slogans while visual forms are all image identifications, the so-called form 
system or system of graphic standards (Szromnik, 2010). In case of enterprises, these elements may form a legally protected trademark that is an asset and can be traded (MalewiczPełczyńska, 2007).

The system of visual identification creates trust in the brand or entity, emphasizing its individual nature. It also makes it easier to memorize it (Smalec, 2014). A correctly designed system of visual identification should be: (1) consistent with the type of a given entity and style of its activities, (2) concise and logical, which allows for its modification and use, (3) original and understandable, which allows for entity identification and for distinguishing it from competition, (4) able to create defined associations consistent with the brand character. A consistent system of visual identification establishes the entity credibility (Wrona, 2012).

\section{Graphic sign - logo}

A basic, most popular and quite often the most important element of visual identification is a logo. A strong image can be achieved by using one or several symbols reflecting the standing of the enterprise or brand (Kotler, 1994). Such a symbol is logo, meaning a graphic sign that identifies a given entity (Macalik, 2013). Logo is the visual identification axis of a given entity. It is around logo that the whole visual communication is built, and this is the most often exposed graphic sign. It defines the style of other designs and imposes the colour scheme. In colloquial language, logo and logotype are synonyms, but one must remember that logo is a wider term and can (but does not have to) be composed of four elements: (1) logotype, that is a name presented with a defined font, (2) symbol (Latin: signatura - designation), being a visual distinguishing feature (3) slogan (brand claim, tagline) and (4) background, being behind other elements (Smalec, 2014).

Logo, meaning the graphic sign of the brand, should fulfil the following functions: (1) phatic consisting in attracting attention, for example with the graphic form (concept) or colours, (2) cognitive consisting in extending the knowledge of the recipient (consumer) about the brand (its name, industry or scope of activities, product type), (3) diversification consisting in distinguishing the product or service from similar products of competition, (4) guarantee that confirms the originality and quality and (5) emotive - the information conveyed by the logotype should be emotional (Macalik, 2013). Moreover, a trademark should be original, simple and universal, and easy to transform (Frączek, 2017).

For logo to fulfil its functions, its use must be standardized. This is made possible thanks to the brand book that contains not only the description of the meaning behind the logo and its elements, but also the rules for its use, its colours, font, protective field, variants, achromatic and monochromatic versions, as well as recommended sizes and backgrounds (Macalik, 2013). The brand book is a set of guidelines that regulates how all the elements of visual identification 
should be used. It is usually a printed document and is also called a CI book or CI catalogue, manual of graphic standards or trademarks book. Standards contained therein are provided as instructions, images, samples and graphic calculations and numeric information (Wrona, 2012).

The website should also be designed according with the rules found in the brand book with the use of corporate colour palette and with the properly selected, readable fonts. Thanks to the consistency with the visual identity of the company, the website reaching a wide audience strengthens the recognition of the brand, transfers vital elements of its "personality" thus strengthening and distinguishing its position on the market.

\subsection{Typology of graphic signs}

The logo should convey information on the values represented by the entity it speaks for (for example-dynamics/modernity, tradition/stability). This information can be conveyed with the use of symbols, colours and selected fonts (Wrona, 2012). Logo is supposed to be a showpiece and a hallmark. A graphic sign does not have to be obvious, but it needs to boost imagination. When referring to an abstract symbol or a metaphor it contains, it should have an effect on the recipient in the aesthetic layer. It is advised to use unique forms that allow to identify and distinguish the owner (Kruszewski, 2011). Establishing a semantics of a graphic sign is associated with the use of several means of artistic expression, among others a tool mark, font, typographic and colour layout. Quite often symbolism, apart from the use of well-defined line, is expressed by archetypal shapes of circle or square. It is similar with colours selected appropriately to the character of the entity (Kruszewski, 2011, p. 232). Colours are of importance and carry an emotional value. Research shows that reactions to colours and perception of colours depend on the age of consumers, their sensibility and attitude towards the message they are receiving. Depending on the mood, colour can have negative or positive influence and associations (Śmiechowska and Dmowski, 2014).

Company logos can be divided into the following categories: (1) inspired by the name of the organization; they express the name of the brand with the use of image, usually are carriers of readable and highly selective information on the company, its sources and activity features, (2) thematic logos; they characterize the object of the business activity of the company; thanks to illustrative properties they reach consumer groups using various languages and of different social backgrounds; (3) symbolic logos; in marketing they equal graphic representation of a given concept, activity or process; (4) logos inspired by heraldry; a coat of arms logo signifies a specific quality, is intended for higher social spheres; (5) logos inspired by letters and numbers; graphic compilation of numbers, letters and words are treated as logos if they do not have distinct features of brand name; (6) alphabets and varied types of handwriting can be used to emphasize the brand and product features and participate in image development; (7) abstract logos; limited to the game of colours, shapes, lines and planes, eliminating the direct presentation of forms observed in nature on purpose (Frączek, 2017). 


\section{Research on graphic signs of rural tourism facilities in Poland}

The subject of the research were the logos of individual facilities of rural tourism in Poland found on the websites of these facilities. The research covered 243 websites hosted on paid domains, including national domain (.pl domain, country code top-level domain, ccTLD), European, commercial, regional and other subscription domains. The addresses were sourced from Agroturystyka.pl. It is a portal run by Polish Federation of Rural Tourism "Gospodarstwa Gościnne". On its pages one can find, among others, offers of rural tourism. What was carried out was semantic, formal and aesthetic analysis of logotypes and names of the rural tourism facilities. The research was conducted by way of exploratory method, using the graphic signs assessment attributes proposed by J. Macalik (2013). Logos were divided into typographic and mixed-typographic ones, comprising thematic, symbolic, heraldic and abstract logos.

In terms of formality, logos were classified according to three groups: (1) typographic, depicting the name of the entity with a given font - a standard one, modified or completely designed without any graphic elements or with insignificant graphic elements comprising an addition to the typographic element, (2) mixed, comprising both letters and graphic elements, usually with dominance of graphics and (3) graphic without any letters, comprising only the graphic element. Mixed logos with dominating graphics were divided into four sub-types depending on what the graphic sign depicts: (1) thematic, consisting of simplified presentation of the facility, architecture of buildings, its surroundings, (2) symbolic, consisting of graphic representation of symbol of a given facility, (3) heraldic using coats of arms, emblems or their elements and (4) abstract (Macalik, 2013). Moreover, what was noted was the name of the facility, theme of the symbol and colours.

\subsection{Results and conclusions}

Logos were found on 202 websites of rural tourism facilities. In 112 cases the logo was composed of a symbol and logotype. All logos except for one used own name of the facility. Only in one case the logo was a symbol without a logotype. It indicates a strong attachment of rural tourism facilities to proper name that is easier to use in direct contact with a customer. The names of the facilities used names or names and surnames of the owners. Such an approach was noted 30 times. Just as often, the names (logotypes) used names of elements of nature; proper names of regions were used less often. Such an approach was noted 49 times.

Proper names of facilities were reflected in the symbols creating a concise message. In 15 cases, an animal theme was noted, including, among others, fish, birds, horses or other farm animals. Just as often the elements of nature were used as the main theme of the symbol, including, among others, hills (mountains), leaves and trees. Items (such as tent, fishing rod, kayaks, boat, cutlery) and persons were noted less frequently. Quite often a graphic depicting a house, curtilage, farmhouse or manor was used in the symbol. Such an approach was noted 
29 times. What was characteristic were also the logos in the form of "text (scraped) in wood", which are typical for rural areas.

The logos were in all colours imaginable, but usually they were in hues of one colour (for example hues of green, yellow, brown). In 131 cases, the logos were assessed as professional. This was evident from the project of the symbol and the manner of logo publication on the website (in high quality). In 147 cases the logos had a traditional form (traditional, not garish, neutral, rustic) or used elements associated traditionally with rural facilities. In 49 cases logos were defined as modern of "bold lines" that could be of interest for younger audiences, which can indicate to whom the offer was directed. In 14 cases the website address was used as a logotype. It is the more useful as the recipient has the opportunity to memorize both the name of the facility and the website address. In 146 cases the logo was used as an element that facilitated the navigation on the website. In the remaining cases logo was only of representative function. In hyper-text documents logo can perform many tasks. Apart from making the navigation easier, they can also have a dynamic, multimedia form. In the set of the studied websites only 7 such cases were notified.

Typographic logos were found on 86 websites. Thematic logos - containing simplified image of farmhouse, house in the countryside, manor with its surroundings, nature, elements of natural surroundings were noted 25 times (Table 1). Symbolic logos containing graphic representation of a symbol, attribute of a given facility, for example horse, eagle, bird, boat, tree, binoculars as well as ears of wheat were noted 57 times. Abstractive and heraldic logos were less frequent.

\section{Table 1.}

Types of graphic signs noted on websites of rural tourism facilities

\begin{tabular}{|c|c|c|c|c|}
\hline \multirow{3}{*}{$\begin{array}{c}\text { Typographic } \\
\operatorname{logo}\end{array}$} & \multicolumn{4}{|c|}{ Mixed, typographic logo } \\
\hline & \multicolumn{4}{|c|}{$116(57.5 \%)$} \\
\hline & thematic & symbolic & heraldic & abstract \\
\hline $86(42.5 \%)$ & 25 & 57 & 11 & 23 \\
\hline
\end{tabular}

Source: own research.

Taking into account logotypes as abstract elements of image management and assuming that they contain the marketing message expected by the sender, two main types of rural tourism facilities were distinguished: (1) traditional facilities, including agritourism ones that carry out a small-scale business (several to several dozen beds) that base their activity on regional traditions and rural practice. These are usually agricultural farms that market their tourist activity with a neutral, traditional, rustic logo, the main theme of which are elements of nature, animals or the farm itself; (2) modern facilities that can be described as "commercialized". These facilities are characterized by withdrawal from agriculture as the main source of revenues, which is replaced by business activity of offering accommodation and associated services, non-typical for rural areas such as SPA or quads. It is associated with focusing business activities in the field of tourism and with the increase of scale and range of the offered 
tourism services (from several dozen to even several hundreds of beds). Commercialization of activities is also understood as change in relations between the owners and tourists (customers). In traditional facilities the customers can count on family hospitality and close relations between the owners and guests. Individual approach to guests is made possible thanks to the scale of activity. In commercialized facilities, guests usually deal with personnel of the facility and the relations are more formal.

\section{Summary}

Logos eluded the adopted classification. Assigning a logo to a specific category was hindered by their varied nature. When browsing the websites of rural tourism facilities, one can deduct that each graphic sign and each string of characters composing a name and written down in any way can be a logo. It is the facility using the "graphic symbol" that decides if it is one or not. In practice, logo is everything that a given facility considers a logo and uses as a logo.

Large and modern rural tourism facilities not always use abstract modern logos. More and more often they market themselves as "agritourism" and use "rural" or "highlander" aesthetics to attract customers looking for traditional rest in the countryside.

Rural tourism facilities use graphic signs, but they are always accompanied by the proper name of the facility. It proves the important role it plays in identification of this facility on the market. In practice of business management, the name of the facility is used and the symbol (graphic symbol) only complements it.

\section{References}

1. Bednarek-Szczepańska, M. (2010). Rola podmiotów lokalnych w rozwoju turystyki wiejskiej na wybranych obszarach Lubelszczyzny. Studia Obszarów Wiejskich, no. 23. Warszawa: IGiPZ PAN PTG.

2. Cai, S. Xu, Y. (2011). Designing not just for pleasure: effects of web site aesthetics on consumer shopping value. International Journal of Electronic Commerce, 15(4), 159-188. DOI: https://doi.org/10.2753/JEC1086-4415150405.

3. Ciepiela, G.A. (2016). Uwarunkowania rozwoju agroturystyki w Polsce. Kwartalnik Kolegium Ekonomiczno-Społecznego Studia i Prace, 1, 37-67.

4. Cooper, C., Fletcher, J., Gilbert, D., Wanhill, S. (1993). Tourism, principle \& practice. Pitman Publishing. 
5. Dewalska-Opitek, A. (2010). Model kreowania zintegrowanego wizerunku przedsiębiorstwa. Zeszyty Naukowe. Polityki Europejskie, Finanse i Marketing, 3(52), 219-229.

6. Frączek, A. (2017). Elementy identyfikacji wizualnej firmy i ich rola w tworzeniu tożsamości. Studia Gdańskie. Wizje i rzeczywistość, 14, 197-218.

7. Kotler, P. (1994). Marketing. Analiza, planowanie, wdrażanie i kontrola. Warszawa: Gebethner \& Ska.

8. Kruszewski, T. (2011). Logo instytucji non profit - modele stosowane w bibliotekach. Biblioteka, 15(24), 231-244.

9. Łuczak, M. (2010). Rola identyfikacji wizualnej w kreowaniu marki i aktywizacji obszaru turystycznego. Acta Scientiarum Polonorum. Oeconomia, 9(4), 277-286.

10. Macalik, J. (2013). Logotyp jako podstawowy element identyfikacjiwizualnej miasta wybrane problemy. Zeszyty Naukowe Wyższej Szkoły Bankowej we Wrocławiu, 1(33), 148-161.

11. Malewicz-Pełczyńska, A. (2007). System identyfikacji wizualnej jako element komunikacji marketingowej. Zeszyty Naukowe Gnieźnieńskiej Wyższej Szkoły HumanistycznoMenedżerskiej „,Milenium”, Zarzadzanie i Marketing, 1, 22-32.

12. Mruk, H. (ed.) (2004). Komunikowanie się w marketingu. Warszawa: PWE.

13. Schmitt, B., Simonson, A. (1999). Estetyka w marketingu. Kraków: Wyd. Profesjonalnej Szkoły Biznesu.

14. Smalec, A. (2014). System identyfikacji wizualnej jako element komunikacji marketingowej na przykładzie Szczecina. Marketing i Rynek, 8(CD), 682-687.

15. Śmiechowska, M., Dmowski, P. (2014). Barwa jako element marketingu sensorycznego i ważny czynnik wyboru produktu. Zeszyty Naukowe Uniwersytetu Szczecińskiego, Problemy Zarządzania, Finansów i Marketingu, 36, 181-191.

16. Szromnik, A. (2010). Marketing terytorialny. Miasto i region na rynku. Warszawa: Wolters Kluwer.

17. Tkaczyk, J., Rachwalska, J. (1997). Wszystko jest obrazem. Kształtowanie wizerunku przedsiębiorstwa, Marketing i Rynek, 5, 5-10.

18. Wrona, K. (2012). Identyfikacja wizualna-jej rola w kształtowaniu świadomości marki oraz komunikacji marketingowej. Prace Instytutu Lotnictwa - Marketing Instytucji Naukowych $i$ Badawczych, 2(222), 233-249. 